\title{
USA \& Brazil in Gantois \\ Power and the Transnational Origin \\ of Afro-Brazilian Studies
}

\author{
Livio Sansone ${ }^{7}$ \\ Department of Anthropology and Graduate Program \\ in Ethnic and African Studies, CEAO, UFBA
}

This article starts with a double statement. In the United States African studies, as a proper field of academic study, originated within the field of African-American studies. Brazil and especially the state of Bahia, which has the highest percentage of people of African descent in the country, took a key place in this process. The style, jargon, priorities, fashions, and methodology of African studies and African-American studies were therefore interrelated, especially in the period between 1930 and 1960. That is when African decolonization started on a large scale and new research agendas were set. The second statement is that there is no history of anthropology and related disciplines outside the geopolitics of knowledge. This posits that in intellectual exchange there is a global North and a global South, with complex relationships between scholars from the North and from the South - in which the latter are mostly, though not exclusively - providers of ethnographic evidence, local contacts and sagacious insights, but seldom the source of universally valid theoretical generalizations-, and that the position of the scholar in this exchange is revealing his or her approach and agenda. Any reading of an ethnographic report has to take into account such context and power relationship. The following text hopes to corroborate both statements. ${ }^{2}$

\footnotetext{
1 E-mail: sansone@ufba.br

2 This paper is based on research in the archives that host the papers of these three outstanding intellectuals, rivals and yet friends. The depositories are: University Archives, Northwestern University, Evanston, Ill.; the Schomburg Center for Research on Black Culture, New York and the Museum of African Art Smithsonian Institution, Washington, D.C for Melville Herskovits; the Moorland-Spingarn Research Center for Research, Howard University, Washington, D.C. for the Franklin Frazier papers; the Anacostia Community Museum and the Melville Herskovits Library of African Studies, Northwestern University, Evanston, Ill., for the Lorenzo Dow Turner. It also includes material from research done
} 
Between 1941 and 1943 the city of Salvador, Bahia became the site of the battle between two different perceptions of black integration in the United States and of the place of Africa in this process. Franklin Frazier, the most famous black sociologist of the time, who had already published The Negro Family in the United States was locked into an argument with the equally famous, white, and Jewish anthropologist Melville Herskovits on the "origins" of the so-called black family. To make things even more complex, both centered their contention on fieldwork done among the same informants: the povo de santo (the members) of the same candomblé house of worship in Salvador - the prestigious and "traditional" Gantois terreiro, of the Ketu/Yoruba nation. In between the two of them was linguist Lorenzo Dow Turner, who would later publish his seminal book on African influences in Gullah, the language spoken by the people of the Sea Islands on the coast of South Carolina and Georgia in the United States (Turner 2003). Turner was a friend of Frazier, but his scholarly theories were closer to Herskovits'.

Frazier's and Herskovits' opposing visions reached a large readership through the publication in the American Sociological Review of an article by Frazier (1942) followed by a response by Herskovits (1943) and a counter response by Frazier (1943). The debate highlighted interesting aspects regarding the way anthropology defines itself as a discipline, different from sociology, as well as the construction of Afro-Brazilian studies as an academic field. It is the story of tension between an American sociologist and an American anthropologist, both using the services of Brazilian intermediaries and gate keepers, who were themselves interested parties in the contention.

The research also shows how already at that time the style and language

at the Museu da Ciência; the Arthur Ramos archive at the Biblioteca Nacional; the Archives of the Museu Nacional, Rio de Janeiro, Brazil. It also attempts a careful reading of footnotes, introductions, book reviews and acknowledgements relating to anything Brazilian in the work of Lorenzo Turner (Lorenzo), Melville Herskovits (Mel, his nickname, or MH) and, Franklin E. Frazier (Frazier).

I owe a lot to a good set of outstanding specialists that have generously shared with me their data and insights: Kevin Yelvington, David Hellwig, Sally Cole, Anthony Platt and Pol Briand, A special thank goes to David Easterbrook of the Melville Herskovits Library of African Studies at Northwestern University; Eleen Elbashir of Moorland Spingarn Center, Howard University; Amy Staples curator of the archives of the National Museum of African Art; Portia James, curator of the Anacostia Community Museum; Dr. Leopold of the National Anthropological Archive of the Smithsonian Institution, and Professor Jean Herskovits. Thanks also to Scot French of the Carter Woodson Institute of the University of Virginia for his assistance on digital history and archives. A special thank goes to Alcione Amos of the Anacostia Community Museum, without whom this paper would have never been written. A slightly shorter version of this paper will appear in the US journal Black Scholar. 
of sociologists and anthropologists - drier or sober for the former and emphatically romantic for the latter - related to radically different approaches to the same phenomenon, in this case, the "origins" and causality of black cultural forms in the New World. Was black culture and family structure the result of slavery and later the adjustment to poverty? Or was it the result of Africanisms, the traditional African forms of life and culture adapted to life in the New World? Beyond these two approaches there are different perspectives on the antiracist struggle. The anthropologist (Herskovits) and the linguist (Turner) stressing cultural differences and considering the strength of culture and its capacity to be resilient to change, versus the sociologist (Frazier) emphasizing the universality of the human condition and the intrinsic changing character of all cultural and social forms. They were stressing cultural diversity versus emphasizing the universality of the human condition; the black person as deserving respect because his culture and personality are intrinsically different or, to the contrary, because he is a human being as any other. Such attitudes, I reiterate, are associated to different political agendas and positioning. The point of difference is how freedom from racism is seen as resulting from the struggle of individuals against it, or as the result of acknowledging the differences and the distinction of black people's culture - which was mostly seen at the time as a collective without individuality.

Reconstructing the research of these three scholars in Brazil, especially around the city of Salvador, Bahia, is important to understand the period that preceded the choice of Brazil as the site for the first large research project by the UNESCO in the early fifties. This project was meant to support empirically the famous UNESCO Statement on Race which came out in $1950^{3}$ as a reaction to the Holocaust and the monstrosity of WWII first and the declaration of apartheid in 1948. The idea behind the research project was to prove that race relations could be harmonious. Central to this project were the activities of Alfred Métraux at UNESCO which aimed at developing a global antiracist agenda. Such UNESCO effort proved to be a major boost to the making of Afro-Brazilian studies and, more generally, to the development and institutionalization of the social sciences in Brazil 4 .

3 The UNESCO Statement on Race is available in www.unesco.org and was originally published in the journal Man, 50 (1950), 138-39.

4 See, in the first place, the work of Marcos Chor Maio, Antonio Sergio Guimarães and, for a collection of articles that also includes Chor Maio and Guimarães, Claudio Pereira and Livio Sansone (2007). 
In the early 1950s, when Bahia became the site of this great UNESCOsponsored project on the study of race relations in Brazil, the research was carried out as a joint project of the University of Columbia and the Federal University of Bahia, with the active support of Bahia's energetic Minister of Education, Anisio Teixeira ${ }^{5}$. In fact, the decision that Brazil and Bahia were the "ideal" site for such a large-scale and politically relevant research on black culture and race relations in the New World was the result of a longer process, which began in 1930 (Domo 2010). It was a process that corresponded to synergy between the cultural politics of the Estado Novo (name given to the dictatorship of Getulio Vargas), the introduction of sociology and anthropology as academic disciplines in Brazilian universities, and the way many foreign scholars, especially Americans and Germans, escaping either racial segregation or Nazism, bought into the official depiction of Brazil as a colorfree democracy. As the book organized by David Hellwig (1992) demonstrated, starting from the nineteen twenties many United States based scholars as well as black intellectuals represented Brazil as an alter ego of segregationist United States. Besides reading Hellwig's book, one can browse the letters addressed by Du Bois to Brazilian presidents ${ }^{6}$, as well as articles by Ralph Bunche, Richard Pattee and Alain Locke and others in several American journals such as the Journal of Negro History, Journal of Negro Education, Crisis and Phylon. For these African-American scholars, Brazil was a positive model for the future of race relations in the United States.

Let us now see how Frazer, Turner and Herskovits contributed, possibly without being completely aware of the consequences, as many other scholars from the North of the time, to creating the conditions for the international celebration of the supposed absence or racism in Brazilian society by the Brazilian Estado Novo populist and authoritarian government. This is not to say that social and racial hierarchies were not changing in Salvador in the

5 My present research deals with the UNESCO projects in Bahia and Brazil more generally. It is a critical reappraisal of that intellectual endeavor and a return to the field. For this project I carried out research in numerous archives and went actually back to the field. I did fieldwork in the region of the same sugar mill were William Hutchison did research in 1950-53 for his PhD under the supervision of Charles Wagley. The title of that research project is "Bahian Counterpoint of Sugar and Oil" Livio Sansone. "Contraponto Baiano do Açúcar e do Petróleo: São Francisco do Conde , Bahia 50 Anos Depois." In Pereira and Sansone, Projeto Unesco, 194-218.

6 Available at the W E Du Bois Papers, 1868-1963, Special Collections and University Archives, W.E. Du Bois Library, University of Massachusetts, Amherst, MA. 
1930s. Society was becoming slightly less hierarchical and for the first time a sizeable component of the intellectual elite started to develop a positive attitude to cultural expressions of African origin in Bahian society. Culturally speaking Africa was starting to be seen as an asset after being seen as a liability for centuries. As an example of the change, Arthur Ramos and Edson Carneiro organized the Second Afro-Brazilian Congress in 1937. It differed from the first congress, held in Recife in 1935 and coordinated by Gilberto Freyre, because it included a number of spokespeople of what in those years was known as the Afro-Bahian community. Martiniano Eliseu do Bomfim, ogã (an honorific character, meaning protector or sponsor of the house) of the famous and traditional Gantois candomblé house of worship was chosen as honorary chairperson of the Congress. A few years later Turner, during his stay in Salvador, would shoot remarkable photographs of this transatlantic character that embodied the importance of the Bight of Benin in the cultural and religious history of Bahia. This religious history later became an important source of inspiration in the quest for African authenticity as basis for power and authority in the candomblé religious system in Bahia and elsewhere so cleverly described by Beatriz Gois Dantas (1988) and others.

A careful look at the proceedings of the Congress reveals a singular combination of the so-called regional intellectuals, nationally renowned intellectuals, and international scholars. Herskovits, unable to attend, sent a paper to be read on his behalf. His paper, presented as a keynote speech, would eventually be the first one in the collection of selected papers published in book format (see Yelvington 2007).

As examples of how Bahia provided a welcoming atmosphere for foreign scholars, especially from the United States, we can start by mentioning Donald Pierson, at the time a doctoral student of sociology at the University of Chicago under the supervision of prestigious Robert Park (for a description of Park's visit to Pierson in Bahia see Valladares 2010). He came to Salvador in 1936 to do pioneering fieldwork among the black community. He was largely convinced that class rather than race mattered in Bahia and that whatever racism one could notice, could be considered a legacy from slavery rather than a sign of modernity. He carried out several interviews, took pictures and made a detailed survey on racial classification and its terminology in Bahia (Pierson 1942).

Apparently, thanks to the network of informants spun by Pierson, Ruth 
Landes, an American anthropologist, also chose Salvador for her postdoctoral research originally meant to focus on matriarchy in Candomblé . Landes, whose thesis supervisor had been no less than Ruth Benedict, accepted Pierson's help in making connections and receiving guidance for her research in Bahia. She did not rely on the famous Bahian anthropologist Arthur Ramos, the key contact person indicated by the Director of the Museu Nacional in Rio de Janeiro, Heloisa Torres. Dona Heloisa, as she was known, was the quintessential gatekeeper of Brazilian anthropology ${ }^{7}$. Apparently that was one of the three reasons that bought Landes the enmity of both Arthur Ramos and Melville Herskovits when she finished her research. The other two reasons were that she had supposedly overexposed the importance of homosexuals in candomblé (something not to be done at the time when Brazilian anthropologists were trying to convince the federal government to accept canbomblé as a "decent" religion) and that she had gotten romantically involved with the well-known Edson Carneiro. This relationship infringed two taboos in Bahia, the one of the American Consulate (having an affair with a black man) and the one of the Bahian elite (having an affair with a communist sympathizer.) (see Cole 1994). Landes left Brazil as soon she completed her fieldwork. In fact according to the French researcher Pol Briand (in a recent personal communication) she was deported with a broken heart. Edson Carneiro would try but never manage to obtain a visa to the United States, to rejoin her. This denial came possibly because of his political leanings. In this respect the correspondence between Landes and Carneiro at the National Anthropological Archive in Washington, DC is revealing. Pierson, on the contrary, stayed in Brazil for many years and became influential in the making sociology a discipline in Brazilian academia. He taught at the Escola Livre de Sociologia in São Paulo, where he resided until the late fifties. In short, Salvador and its Afro-Bahian community was in those days an important

7 In those years, characterized by the authoritarian Estado Novo government of Getulio Vargas (193645) foreign researchers in Brazil needed an authorization that was issued by the then very repressive Ministry of Justice. This was done often in collaboration with the Director of the Museu Nacional. There is evidence at the Museu archives that Lorenzo, Franklin and Mel got such permission. Foreign scholars signed a document in which they guaranteed that a copy of the book or report resulting from their research in Brazil, would be sent to the Museu Nacional. This often did not take place. Of the three scholars studied in this paper only Herskovits sent a report, in spite of the letters of reminder by the Director of Museu Nacional. None of the three, however, ended up publishing the book on Brazil they were supposed to publish according to their grant application. 
crossroads for international sociology and anthropology as well as an important source of inspiration for antiracist thinking. (Corrêa 1987).

On December 8, 1940 Lorenzo Dow Turner arrived in Salvador together with sociologist Franklin Frazier. Their arrival is announced on the front page of the main Bahian newspapers. ${ }^{8}$ They had had a short stay in Rio de Janeiro and a detour to São Paulo, where they gave a lecture at the Escola Livre de Sociologia at the invitation of Pierson. Frazier came from Howard University and Turner from Fisk University - Landes had spent a period at Fisk before coming to Bahia. Frazier had a grant from the Guggenheim Foundation. Actually, Du Bois wrote to Frazier to congratulate him for this award, being the first time a black person had received such prestigious grant. Turner received a grant from the Rosenwald Foundation, specialized in providing funds for black scholars. As can be read in the positive evaluation report of the grant application of the three scholars, their visit to Brazil could in fact contribute to the several cultural-diplomatic activities sponsored by the "Good Neighbor Policy" through which the American government and especially the Rockefeller Foundation were trying to increase the mutual understanding between the two countries. The hidden agenda of such policy was to counteract the neutrality of part the Brazilian government in the early stage of the Second World War. Consider that for Brazilian public opinion at the time the United States was the land of institutional racism. The argument of many in the Brazilian neutralist front was: Why fight German Nazism and defend American segregation? (see more on the history of the Good Neighbor Policy http://www.u-s-history.com/pages/h1646.html and in Williams 2001: 192-250).

As part of this large pre-war effort, that also included cooperation in the field of scientific research and public health, the United States also sent to Brazil two other famous Americans, Orson Welles and Walt Disney. The first arrived in 1942 and shot intensively, in his peculiar style, images of popular culture during six months. This resulted in a brilliant short documentary entitled "Four men on a raft" 9 . This should have been the first episode of a

8 These pages may be consulted at the Moorland Spingarn Center and the Museu Digital da Memória Africana e Brasileira (www.arquivoafro.ufba.br). There one can consult a number of collections. Especially relevant for this text are the following: Lorenzo Dow Turner; E.Franklin Frazier; Melville Herskovits; Donald Pierson; and Ruth Landes.

9 See an interview with Orson Wells and clips of the documentary at http://canhotagem.blogspot. 

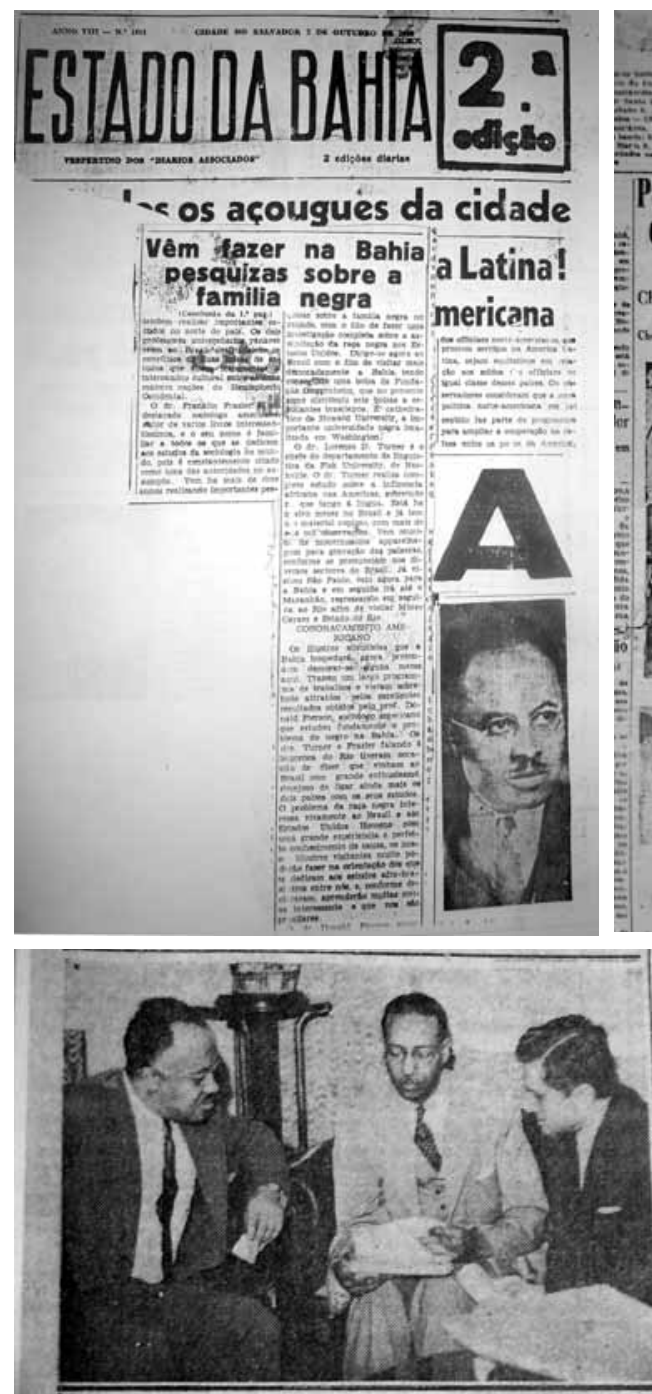

VIRRAM ISTUDAR a contribuicã̃o africana na formação do Brasil

"O GLOBO" OUVE OS PROFESSORES AMERICANOS FRAZIER E TURNER

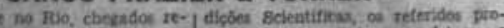

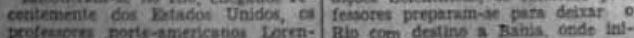

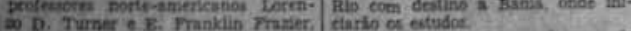

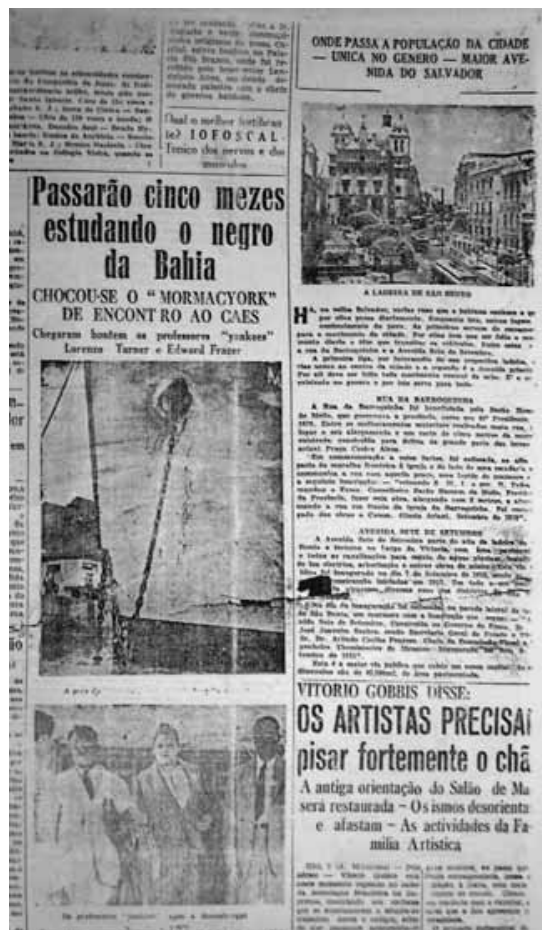

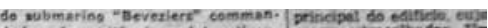

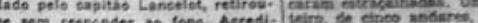

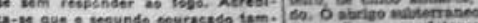
Eem tenhis side attingids. Os obu- Prims fieco menpintame

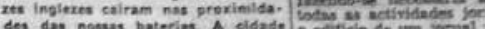

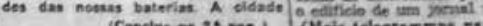

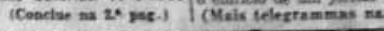

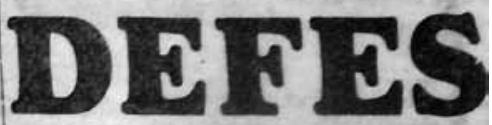
ECONOMICA DO BB

A NOVA LEI SOBRE A ORGANIZA SOCIEDADES POR ACCOEES PERM FORMACÁO DE EMPRESAS ESSEN DESENVOLVIMENTO DO $P_{1}$ FALA AO "GLOBO" OSR. MIRAND, DE, AUTOR DO ANTE-PROJE 0 chafe do Gorerno anitron vas

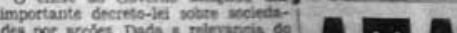

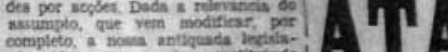

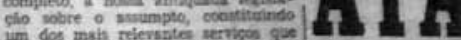
im doe mais reievsites servipos pue de revisio das nomas leik, procurimat ourte o st. Trujano de Murabla Val-
verde, autor da ante-projecta, ara Todantormado em lei.
Tociedade por acçóes

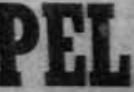
é mercantil

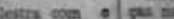

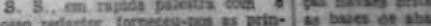

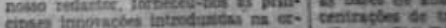

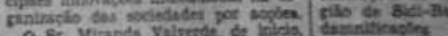

E. Franklin Frazier Pappers, Moorland-Spingarn Documentation Center, Howard University, Washington, DC 
longer documentary rich in images of the Carnaval in Rio entitled "É tudo verdade" (It is all true.) Most of the footage portrayed Brazil as largely mulatto and black. The images of the Carnaval in Rio in particular demonstrated that it was largely a black and lower-class celebration. Because of this "blackening" of Carnaval, associated with what was then considered as extravagant drinking and social behavior, Orson Welles never actually enjoyed the glory he deserved as a documentary film maker and was sent back to the United States prematurely. In 1993 this unfinished oeuvre was assembled in a French produced new documentary with the same title "It is all true" 10.

With Walt Disney the story was altogether different. In 1942 he produces his cartoon Saludos Amigos. His 1944 cartoon "Você já foi a Bahia" (Have you been to Bahia?)" launched the character Zé Carioca, the hustler like merrygo-happy parrot that should represent the soul of Brazilians. This tropical stereotyping went down much better with the Brazilian elite and in the eyes of the planners of the "Good Neighbor Policy."

It is worth remembering that in those troubled years Brazil was thought to be a possible safe haven not only by American blacks, but also for European Jews. Frazier and Turner came to Brazil in the same year the wellknown Austrian and Jewish writer Stefan Zweig and his wife came to Rio. It seems that their first impression was similar and positive. They were delighted to see the racial interaction in public schools and in children's homes. There is evidence that these positive representations of race integration in Brazil by foreign black and Jewish intellectuals influenced each other (Zweig and Zweig 2010; Dines 2009).

Incidentally, in the Franklin Frazier Papers at the Moorland-Spingarn Research Center at Howard University one finds several folders where Frazier kept newspaper clippings of lynching episodes in the United States gathered in the period just before leaving to Brazil. He was somehow obsessed with the lynching of African-Americans and was moreover well known to be a tit for tat fighter against everyday racism. For instance, he sued several segregated establishments for refusing him entrance. He also did not accept

com/2009/12/que-verdade-e-esta.html (accessed Feb. 24, 2011)

10 More information at http://en.wikipedia.org/wiki/It\%27s_All_True_\%28film\%29|(accessed Feb. 24, 2011)

11 See the film at http://www.youtube.com/watch?v=JSBxYcxnhf8 (accessed Feb. 24, 2011) 
invitations from academic institutions if it meant he would be subjected to segregated facilities or travel. No wonder then that as soon as he arrived in Rio he gathered brochures of such institutions as the Instituto Central do Povo and the Orfanato Ana Gonzaga in which racially mixed groups of kids were portrayed ${ }^{12}$. Horror had given way to amazement in Brazil. Both men had left behind horrors - anti-Semitism and racial segregation. Zweig committed suicide in the Brazilian town of Petropolis together with his wife in 1943 after publishing the marvelous book entitled Brazil, Country of the Future and leaving a letter of apology to the Brazilian people(Spitzer 1989). Frazier returned to the United States strengthened in his opinion that humanity was possible for black people in the New World, in the context of modernization and industrialization.

Frazier had already gained acceptance in certain circles of the academic world and even within the Roosevelt government. He came to Brazil to lecture on his book and on the situation of the black population in the United States, but also to collect material to back his theory that it had been slavery and adaptation to poverty, that had influenced the family structure of the black population. For that purpose he traveled straight into one of the regions of the New World that, according to Herskovits, were the strongest depository of "Africanisms" - the city of Salvador and especially the community around one of the most traditional candomble houses of worship, the Gantois. In his Bahian expedition he profited from the network laid out by his fellow Chicagoan and sociologist Donald Pierson. Pierson introduced him to a set of key people in the Bahian intellectual elite and warned him not to rely too much on American anthropologist Ruth Landes (who, as I said earlier, had infringed the American racial code and the Brazilian social code, by having a relationship with black communist sympathizer Edson Carneiro and having "gone native" in her fieldwork. In her book, moreover, she supposedly overexposed homosexualty in candomblé houses - exactly when Herskovits and Arthur Ramos were struggling to have canbomblé accepted as anthropological object and religious system in its own right (see Cole 1994; Fry 2010.)

In doing fieldwork Franklin Frazier, who apparently was able to interview people in Portuguese without an interpreter, teamed up with linguist

12 E.Franklin Frazier papers, Moorland-Spingarn Research Center, Howard University, Washington, DC, box: 131, folders 133 through 137 (hereafter cited as Frazier Papers). 
Lorenzo Dow Turner, who had unique recording equipment with which he recorded many hours of interviews with candomblé priests and priestesses, as well as music, folktales and short stories. Turner also took over two hundred pictures, including several of Frazier's informants. In the following years Turner, with African assistants, transcribed hundreds of pages of folktales in African languages, mostly Yoruba, which he had collected in Brazil. Only part of these transcriptions was translated into English. Eventually Turner's research would result in three published articles (Turner 1943, 1957 and 1958), besides the recordings, transcriptions of folktales and photographs. It is a pity that because of several constraints, including financial, and in spite of several attempts, Turner never managed to publish those unique transcriptions in book format. Margaret Wade-Lewis (2007), in her detailed biography of Turner mentions that in fact Turner had plans to publish three books with the result of his fieldwork in Brazil. These transcriptions - the Federal University of Bahia has copies of them kindly provided by David Easterbrook of the Africana Library at Northwestern University - are a rarity that still have to be studied by a contemporary Yoruba linguist and scholar. Nevertheless, they seem to provide evidence that African languages were in current use in Salvador in the 1940s, not just as part of the religious language of candomblé, as it is today.

The daily experiences of these black scholars in Salvador were remarkable and certainly quite different from daily life in the United States. Upon reaching Salvador by boat they were picked up at the port by the American Consul (who had almost certainly never before welcomed black intellectuals of such standing to Bahia) who now had to welcome two American black scholars with pomp. Their arrival was announced on the front pages of all main Bahian newspapers and they checked into the centrally located Hotel Chile (one of the best hotels of the city, possibly the best, where other intellectual foreign visitors such as Ruth lands had also stayed.) They had a white driver dressed in a white suit and bow tie and took individual Portuguese language lessons with a lady living in the bourgeois Campo Grande square. They enjoyed Carnaval and the popular Senhor do Bomfim street festival in the company of a group of light skinned middle class girls, as clearly shown in the picture Turner shoot (see Turner collection in www.arquivoafro.ufba.br). In other words, both Turner and Frazier could circulate at will in both popular culture and traditional religious circles as well as among the elites of Bahia. 
Frazier and Turner very likely were able to experience this freedom because of their American citizenship and hard currency.

Their presence did not go unnoticed by the intellectual white elite; after all they were most certainly the first American black scholars to carry out fieldwork in Bahia and perhaps the whole of Brazil. In a letter of December 1, $1944^{13}$ to Melville Herskovits, José Valladares, his key contact in Bahia as well as a renowned art-historian and curator of the prestigious Museu da Bahia, described Franklin Frazier as arrogant and mulato frajola, a showy mulatto. The Bahian elite who had been very welcoming to white American scholars and travelers was not apparently as happy with their fellow black Americans.

In August 1941, soon after Frazier's short fieldwork and the slightly longer fieldwork by Turner, the Gantois house received the visit of Melville Herskovits, in the company of his wife Frances and young daughter Jean. In 1937 he was already well-known to Brazilian social scientists. As we have seen he had sent a keynote speech to be read at the Second Afro-Brazilian Congress held in Salvador, Bahia. Herskovits, as suggested by a set of family photos portraying him with his daughter and wife Frances, rented a small apartment from the Edith Guesthouse in the building that is now known as Casa de Itália on Campo Grande, right in the center of Salvador - a comfortable but less flashy accommodation than the hotel Palace. He had the help of a prestigious interpreter, the intellectual and well-positioned José Valladares, who had been the secretary of the Second Afro-Brazilian Congress. Valladares was an architect; art historian and writer ${ }^{14}$. He was also married to Gisela, an American who had been trained in anthropology and who later became involved with a research project on race relations in Bahia sponsored by the Universidade Federal da Bahia in conjunction with the Columbia University and Unesco (Wagley 1952; Azevedo 1966).

In Bahia Herskovits relied on a different network from that of Frazier and Turner. He had much better connections with the Brazilian intellectual elite. His primary contact was Arthur Ramos, considered the dean of Afro-Bahian studies, with whom Herskovits had been and continued to be corresponding quite a lot (see Guimaraes 2007) and had the endorsement of the director of the Museu Nacional, the famous Dona Heloisa Alberto Torres (Correa \&

13 Melville Herskovits Papers, Northwestern University Archives, Evanston, Il., box 36, folder 2.

14 See among others his books Be A Ba da Bahia of 1956 and Museus para o povo of 1944. 
Mello orgs. 2009). Herskovits interviewed about the same cohort of people as Frazier and Turner. He also came to opposite conclusions than those of Frazier. He concluded that Africanisms basically explained the matrifocal family arrangements of the Bahian black and poor. For the former matrifocality was a basically Western African family pattern that had maintained itself alive across time; for the latter matrifocality was a creative adaptation to life under uncertain social conditions and was a survival strategy of the poor in many parts of the globe much more than the result of any cultural pattern.

As is well known this sociology (Frazier) versus anthropology (Herskovits) context would have a great impact on the debate on the causes for the matrifocality of many black families as well as on the relationship between poverty and culture in the black population in the United States. This was especially apparent during President Lyndon Johnson's War on Poverty effort.

Turner's work fell somewhere in between even though it tended towards Herskovits' notion of Africanism. He believed that the strength of black culture and its language rested in its capacity to retain elements of its African past in the present. When compared to Frazier, Turner was less concerned with structure and more with culture. He was convinced that the dignity of blacks had to be based in their capacity to experience and be proud of their culture.

Let us now compare the style of fieldwork of these three important scholars. As we have seen, Turner teamed up with Frazier. The former had a gasoline propelled Edison recorder, an expensive rarity in those days. It recorded on aluminum discs that played 15 minutes at the most. Turner also knew how to operate this complicated machine. He was well trained in linguistics and had a general interest in music and how it interacted with language. Herskovits teamed up with his wife Frances, a self trained ethnographer who would eventually transcribe his field notes and interviews and would maintain interest in Brazil until the end of her life. In fact she went back to Bahia in 1968 for follow-up fieldwork and after the death of Herskovits, she tried very hard, albeit unsuccessfully, to publish a book with their findings on Bahia.

The international and Brazilian networks of the three scholars were very different. Frazier relied on the network established by Chicagoan Donald Pierson and later Ruth Landes in the years 1936-39. Upon arrival Turner and Frazier had already identified a number of contacts in the political elites as 
well as among the key middle class families in the black population. Both Pierson and Landes had relied for contacts and guidance on the black and communist sympathizer, journalist and self-taught ethnographer Edson Carneiro. As seen before, Landes actually made him the central key informant in her fieldwork. It is quite possible - though I have not found evidence in the archives - that the contacts in the candomble world, especially the famous Gantois house, that Turner and Frazier interviewed, were the ones arranged by Ruth Landes and Edson Carneiro. Herskovits had better connections with the white intellectual elite already from the start and found in José Valladares a great local ally. Turner benefited from the contacts and fluency in Portuguese of his friend and colleague Frazier - a polyglot -, and Frazier benefited from the recording methods, photographic skills and the company of Turner.

Frazier's style and academic-political project can be discerned through his fieldwork notes. For defining characters, positions and manners of the candomblé religion he used native terms, such as casa (house), seita (sect), and zelador (caretaker) for referring to the temple, the religion and the priest and priestess. He seemed to bestow relatively little importance to things African and sometimes he outright downplayed African memories. In his interviews he asked what people knew of Africa, what African words they knew, and whether their origin was African. In his comments he consistently suggested that daily actions, survival strategies, and family arrangements were informed by present circumstances much more than by any African past. All of Frazier's field notes and interview transcriptions contain name and basic data on the informant. He also took pictures of all the informants, even the simple people of the "povo de santo," the followers of the Gantois candomblé house and every picture is numbered and has the name of the person portrayed written at the back and a number in the front for helping identifying the informant. This is the method he had used in his research on the black family and church in the United States. It seems to suggest that Frazier meant this short but intensive fieldwork as a pilot study to be continued and expanded. It is as though he had plans to get back to the same informants at some point.

Turner's fieldwork method is radically different in some ways and quite similar in others. He left no fieldwork or methodological notes - in fact there are no such notes regarding Brazil in his papers at Northwestern or at the Anacostia Community Museum. Yet, from the recordings, interview 
transcriptions, notes, and, later recollections of his experience in Bahia, we know that he showed to his informants a list of words (and perhaps expressions) he had gathered from the Gullah and he played to them recordings of the African-influenced speech of the Gullah. Turner recognized in the Bahia speech several expressions he had heard from the Gullah and now his informants also recognized words in the written lists and recordings. Without questioning that several African expressions are similar in both contexts - and in this respect Turner research technique was well advanced and legitimate for the time - with the hindsight of history one wonders today if in this process of recognition of African words and heritage should not also be taken into account that the Bahian informants wanted to give a socially satisfactory answer to the friendly, well-educated and African-oriented black American linguist.

All of Turner recordings and many of the photos he took also have names and descriptions facilitating the recognition of the informants. In this he resembled Frazier's fieldwork style. Turner and Frazier were certainly interested in social and cultural phenomena, but were also inclined to name and humanize their informants. They saw people before and behind these phenomena. Moreover it is obvious that in those days the photos they took were possibly the first and only portraits these often very poor people had of themselves. This helps to explain why all the informants appear nicely dressed up in the photos taken by Frazier and Turner in Bahia ${ }^{15}$.

Herskovits' style and project speaks, just as well, through his field notes and music recordings. His field notes, taken in note pad and later typed out (and possibly expanded) by his wife Frances, amount to about 500 pages of interviews and observations. They are cataloged according to themes. No names of informants are mentioned, expect when it concerns important characters of the candomble religion. Opposite to Turner, who in his music recordings always indicated the name of the author or musician, Herskovits

15 To understand the importance of the photographs taken by Turner one must remember that in those days and until the present a popular expression in Brazil for taking a picture of a person is "tirar retrato" (making a portrait.) This is a reminder of a recent past in which most poor Brazilians had one or two pictures taken through their whole life. One was taken at their wedding and, for men, a snapshot on the work permit. The original photographs taken by Turner are held by the Anacostia Community Museum of the Smithsonian Institution in Washington, DC. Most of the photos taken by Turner, Frazier and Herskovits in Bahia can be seen at the Digital Museum of African and AfroBrazilian Heritage, www.arquivoafro.ufba.br . 


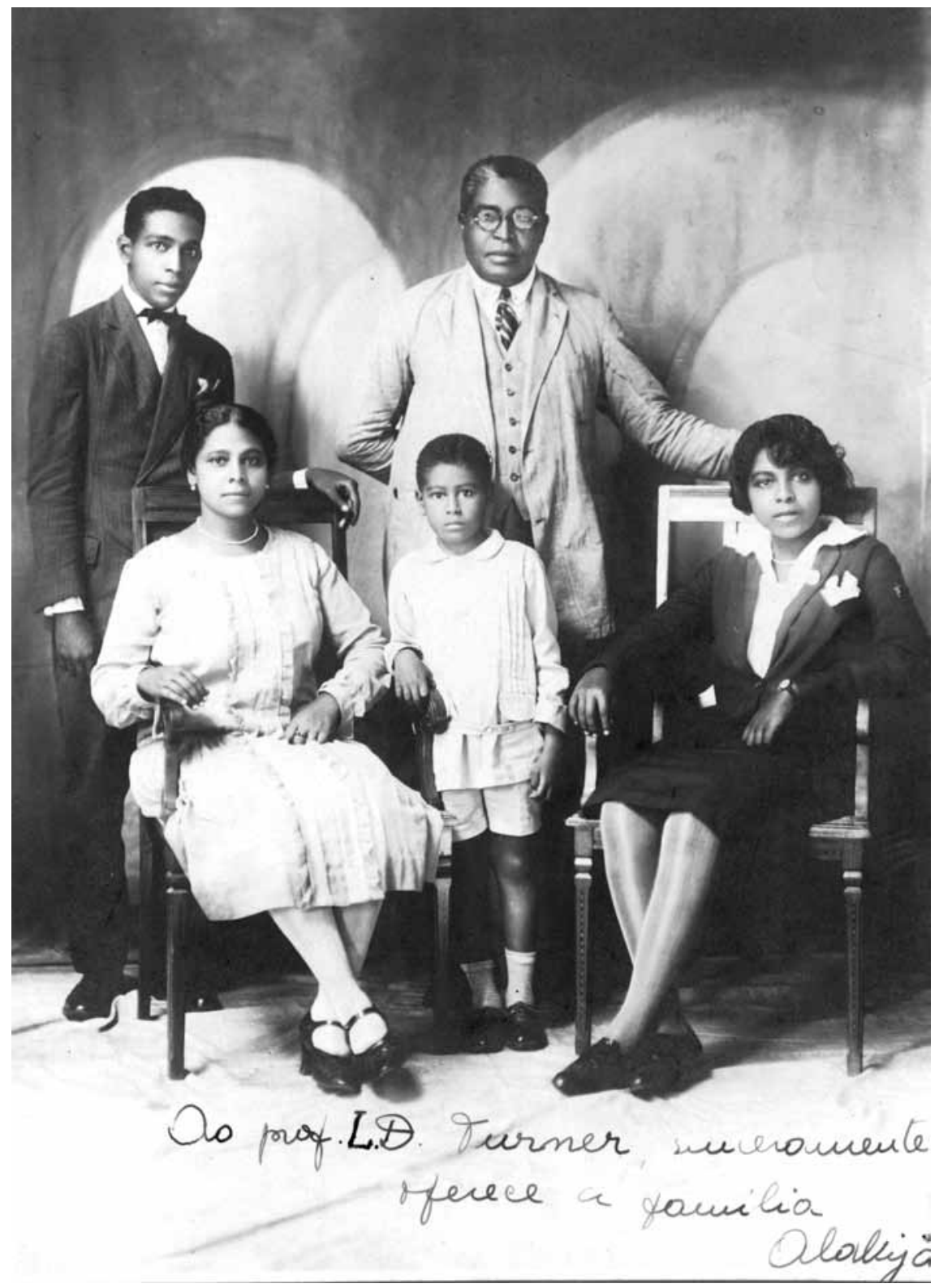

Porfírio Maxmiliano (Maxwell) Alakija (Assumpção) and family in Bahia. Date unknown. The Assumpção/Alakija family had branches in Salvador and Lagos, Nigeria. Lorenzo Dow Turner Papers, Anacostia Community Museum Archives, Smithsonian Institution, gift of Lois Turner Williams 
music recordings, which were later published in a compilation by the Folkways series of the Smithsonian, never mentioned the name of the musician, but just to which orixá that particular drumbeat was dedicated.

In similar fashion to Turner's technique, Herskovits submitted to his informants, lists of words in African languages, especially relating to the religion he had researched while doing research in Dahomey (presently Benin) and in writing the two books he published on the Yoruba religious system in Africa. Herskovits, in fact as much as Turner and Frazier, came to Salvador to test the results of research he had carried out somewhere else. In these lists Herskovits places a number of terms in Yoruba, such as babalorixa as referring to the priestess of the Candomblé, that were not in use in Bahia at the time but came into common use by scholars afterwards. Other terms were used by Herskovits that were not (so) native - religion instead of sect, and terreiro (yard) instead of casa (house). In many ways one can say that Herskovits had a mission to describe candomblé as a proper religion, rather than as a syncretic cult mixing African elements with popular Catholicism and evil-eye practices as it was often portrayed in the local press. In doing so Herskovits broadened and made more sophisticated the research already carried out by Brazilian scholars Arthur Ramos and Edson Carneiro, of whose work he was very much aware.

Similar to Turner, Herskovits tried in his interviews to wake up African memories and he also wanted to find Africanisms. It is worth bearing in mind that the 1930s had been the founding years of Brazilian anthropology. It had also been a period of symbolic incorporation of the African origins of much of Brazilian popular culture and religion into the official cultural representation of the nation by the populist dictator Getulio Vargas (Williams 2001; Sansone 2003). Such process, it goes without saying, made of Brazil an even more interesting place to come to and to do research on the AfroBrazilian population.

The three scholars interviewed basically the same nucleus of people around the candomble house of Gantois. Frazier identified his informants and so did Turner. Frazier also interviewed approximately forty people, mostly women, who lived near the Gantois and twenty people of the so-called black elite (doctors, lawyers, and businessmen.) Turner interviewed also a number of key people of the well-known black families who had relatives in Nigeria or Dahomey. Turner gained acceptance by these families and one can imagine 


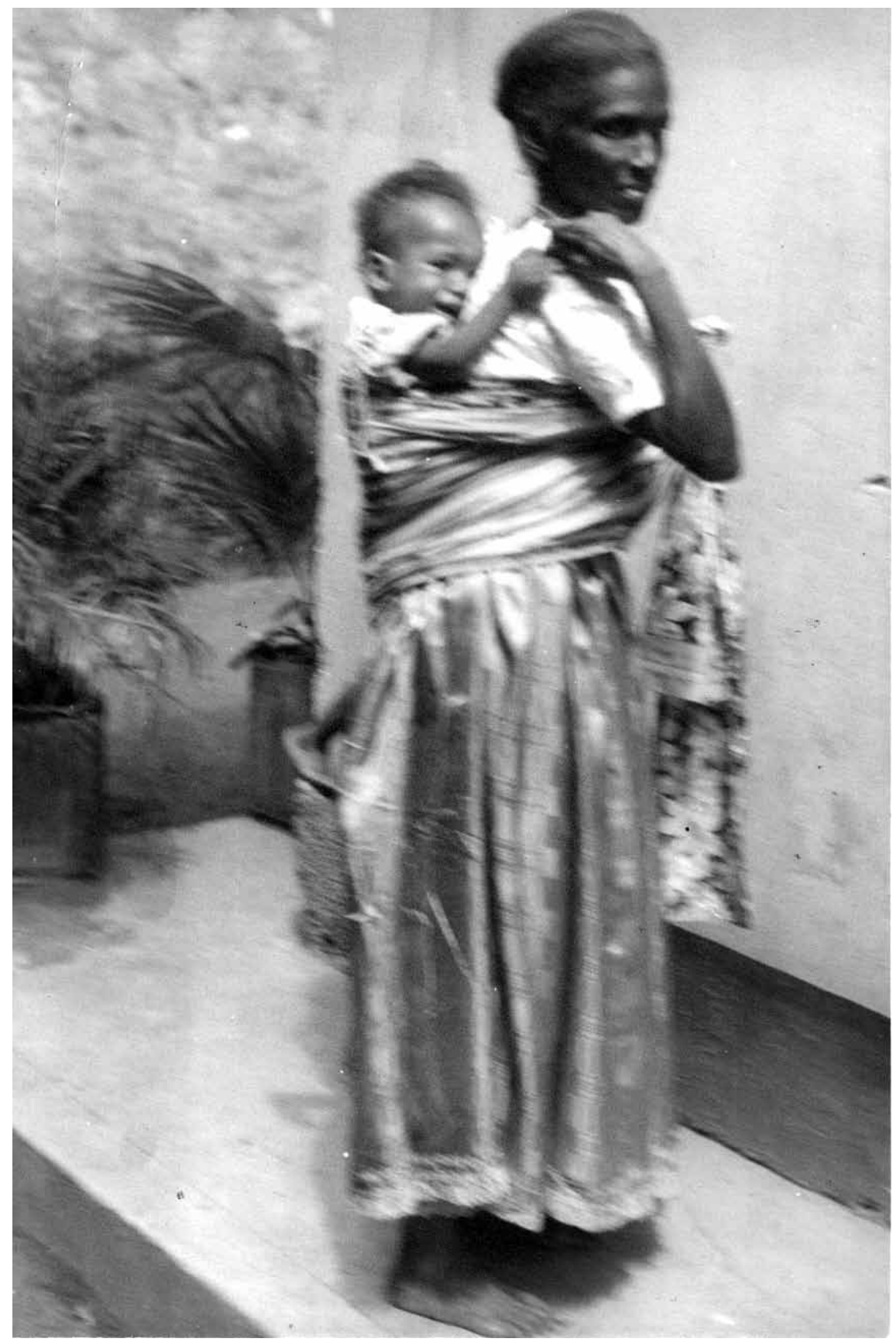

Afro-Brazilian Woman Carrying a Baby on her Back in the African Fashion Lorenzo Dow Turner Papers, Anacostia Community Museum Archives, Smithsonian Institution, gift of Lois Turner Williams 
that it is because of this that he obtained from his middle-class informants copies and originals of a passport of Bahian blacks returning to Africa as well as pictures of these families in Bahia and Lagos ${ }^{16}$.

Herskovits focused his research on the priestesses (mães de santo), their immediate followers (daughters of the house and religious assistants), and on the male character of the ogãs (protectors of the house.) In short, Herskovits, very much in line with Ramos and Carneiro, focused on the religion while Turner and Frazier focused on the community around the candomble house.

It is worth mentioning that the black elite were the topic of the Columbia University and Unesco sponsored research carried by Bahian anthropologist Thales de Azevedo (1966 and 2008) My impression is that Azevedo relied largely on the black families who had been contacted by Pierson (and possibly Landes) and later photographed and interviewed by Turner and Frazier. Turner and Frazier, however, identified their contacts in their field notes, interviews and photo captions. In their books neither Pierson nor Azevedo, who also published a number of pictures of black middle class people, mentioned their names.

There were a few other differences regarding the relationship of these scholars with their informants and the research subjects. Herskovits paid for his information and he kept a careful list of all payments from the moment he left New York to the moment he was back. As the recent book The Root of Roots by Richard and Sally Price (2003), which deals with the Herskovits work in Suriname in the year just prior to the trip to Brazil, this was not an uncommon practice in their fieldwork. The Herskovitses also kept in contact with some of their key informants in Bahia over the years. Herskovits' papers at the Schomburg contain a number of letters by canbomblé priestesses asking for financial donations to their houses of worship. As far as I know neither Frazier nor Turner paid money to their interviewees. My impression is that they were well accepted for a three reasons: they were competent scholars, they were American, and they were black showing interest in Brazilian blacks.

Another difference is that Turner and Frazier, though quite interested and respectful of the hierarchy, discipline and mission of the Gantois and of candomblé in general, never took the formal position of ogã or obá de

16 For more on the Afro-Brazilian returnees to West Africa in the $19^{\text {th }}$ century see Alcione $M$. Amos (2007). 


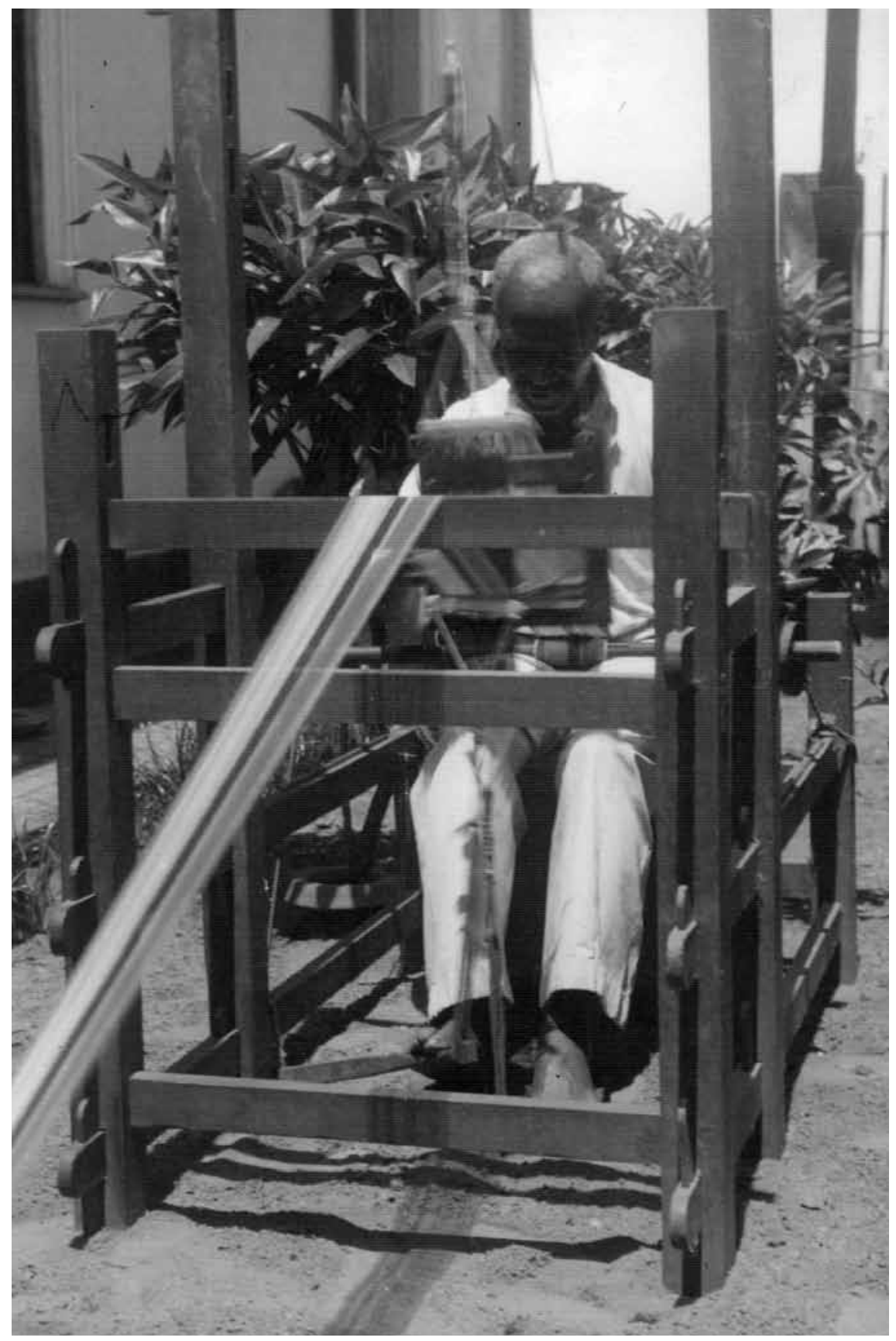

The last weaver in African style on record - a tradion interrupted that has recently been revived. Lorenzo Dow Turner Papers, Anacostia Community Museum Archives, Smithsonian Institution, gift of Lois Turner Williams 
Xango- that is protector of the house - that had been given to Herskovits and other scholars. This position was given to well known artists such as Jorge Amado and to politicians and to scholars doing research in or around the Gantois and other prestigious candomblé houses. Some of them were Nina Rodrigues and Arthur Ramos in earlier years, and Roger Bastide, Alfred Métraux and Pierre Verger afterwards. There is no concrete evidence of race having meant major barriers for the fieldwork of Turner and Frazier, actually from their correspondence one gathers that they had quite a lot of fun and enjoyed the freedom to move across different social environments. I see two possibilities for the fact of the two scholars not having taken such honorary position. It is possible that because of the racial politics and discrimination which was prevalent at the time, black foreigners, even if American citizens and well-known scholars, were simply not easily invited to take any honorary position in the candomble house. Another possibility is that Turner and Frazier, because they were black, did not need to take such formal positions in order to gain acceptance in the candomblé community.

Last but not least, the three scholars differed in the way they photographed their subjects. When we compare the composition of the photographs, Herskovits is never portrayed next to his informants. When there is a portrait of him in Bahia, he is next to his family, fellow anthropologists or José Valladares - his main contact person. Herskovits, moreover, took many more photographs of objects such offers to the gods, magic trees, sculptures of orixás, and musical instruments. He photographed very few of people other than those within the candomblé community. Frazier was twice portrayed next to his informants, even holding the hand of a small child. Turner took photos of ordinary Afro-Brazilians, besides of his informants. He attached a small description to each picture, often referring to the ability of the subject to speak Yoruba or another African language.

They also differed in terms of the antiracist agenda. Turner and Frazier were not only black scholars with an antiracist agenda; they were also interested in meeting important black people, the black elite. Herskovits had an antiracist agenda of his own, but was much less interested in black agency and even less so in the black elite (see, among others, Gershenhorn 2004). One can imagine that he preferred "authenticity" in Africanisms rather than people who behaved in many ways as white intellectuals or the white upper class would. 
Behind these different approaches in their research methods there were rather diverging positions by these three scholars regarding the African heritage of their subjects. Turner and Herskovits were convinced that the African past offered the kind of cultural grandeur they saw as necessary for black people to struggle for libration in the United States. Frazier was not at all convinced that the past was a potential ally for black liberation, in a position surprisingly reminiscent of Frantz Fanon's interpretation of the past as a fetter the oppressed have to come to terms with through a symbolically violent rupture (Guimaraes 2008). Frazier was rather more interested in the future, in the place of negritude within modernity. This attitude was largely a political stance against what Frazier saw as the stereotypical generalizations of the reconstruction of black grandeur based on the past ${ }^{17}$.

In this context Herskovits had the upper hand. He had spent more time doing fieldwork, and his approach to African culture in Brazil fitted very well with the renewed attempt of several Brazilian intellectuals to redefine national-popular culture. Moreover he also had better and more powerful connections with the rising Brazilian anthropology community, both in Bahia and at the Museu Nacional in Rio (in those days the absolute national center of Brazilian anthropology.) Herskovits also had better access to funding for research abroad and was in a better position to invite Brazilian scholars to visit the United States ${ }^{18}$.

As we know, Herskovits left his mark on the anthropology of AfricanAmerican cultural expressions in the New World. He was also attractive to Brazilian academia, so much that in May 1943 he was invited to give the keynote speech in the opening of the Faculty of Philosophy of Bahia (today the

17 Turner and Frazier would hold on to their diverging position as to possible Africanisms in black American culture, and yet be interested in the future of post-independence Africa for the rest of their life. They would both contribute to the special issue of the journal Présence Africaine edited in book format and dedicated to the theme of American blacks and Africa (Frazier 1958; Turner 1958).

18 Lack of funding hampered both Turner's and Frazier's plans to do research in Africa and to develop African studies in their institutions (Fisk University and later Roosevelt University for Turner and Howard University for Frazier.) For example, while Herskovits was able to use the help of a number of $\mathrm{PhD}$ students, Turner had to rely on African informants in the United States and had fewer opportunities to do research in Africa. Turner finally went to Africa in 1951 with a Fulbright grant and later on worked on the Krio language with grants from the Peace Corps. Frazier had to wait until his year at the UNESCO in Paris in the late 1950's to be able to work with Africanists and African scholars in the organization of the first conference on industrialization in Africa. 
Faculty of Philosophy and Social Sciences, FFCH of the UFBA where I work) ${ }^{19}$. He also appealed to the canon of anthropology of his time especially the romantic motives of the Cultural and Personality School with its passion for Apollean groups and cultural forms. This fit well with the Yoruba claim of uniqueness, purity and authenticity in religion.

Even though he initially intended to, Herskovits never got back to his Gantois informants. In 1954 he did come back to Brazil, to attend the International Latin-American Congress. His daughter Jean, who was with her parents in Bahia as a young girl and later became an Africanist, told me that he actually also went back to Bahia on that occasion. However, he never went to the candomblé house that was so important in his fieldwork and that also had become important in his personal life. According to Jean, Herskovits was quite superstitious and always impressed by the magic and future telling power of candomblé. Jean told me that her parents were convinced that their lives were saved by candomblé. When it was time to go back to the United States they were convinced not to get on that boat (they will eventually fly back to the US) by a group of candomblé priestesses who gave them a wooden Xango ax that would protect them. The boat in which they would have traveled, the vessel SS Bill, was indeed sunk by a German submarine, and in it was lost a copy of the recordings and field notes and all the AfroBrazilian artifacts the Herskovits had purchased in Brazil for the museum at Northwestern University (see MH Papers at Northwestern University, Box 4 Folder 12). Luckily Herskovits had kept a copy of his recording and field notes with the American Consulate in Salvador and had sent a second copy by mail to the United States. As I could see personally, this wooden ax is now a cherished object in Jean Herskovits' New York home, a bitter-sweet reminder of Bahia, candomblé and her parents.

19 The text of his speech is in Melville Herskovits, The New World Negro: Selected Papers in AfroAmerican Studies. (Bloomngton, Indiana: University of Indiana Press, 1966) and translated into Portuguese by José Valladares. It was the text presented as final research report to the Museu Nacional in Rio and was first published in Brazil in 1944 by the Museu de Arte da Bahia, with a foreword by Isaias Alves, the first head of the Faculty of Philosophy of the Federal university of Bahia. The journal AfroAsia published again in 1957 (available on WwW.afroasia.ufba.br) and the Museu de Arte published a third time in 2008. On the contrary no translation into Portuguese is available for the articles written by Turner and Frazier. Of course one can wonder about the effects of this politics of translation for the construction of the hegemony of Herskovits' paradigm on Afro-Brazilian studies and Afro-Latin studies in general (see Yelvington 2006). This paradigm was buttressed by a number of prestigious scholars that followed its path such as the well known French scholars Pierre Verger and Roger Bastide. 
Between 1941 and 1943 Frazier published six articles on race relations in Brazil and the black family in Bahia (see list in References). Brazil became pivotal in supporting his argument about both the black family and on race being the real American Dilemma. These were the years that lead to the preparation of Gunnar Myrdal epochal book. Frazier gave a contribution to this book but the extent of it has recently been subject to debate. Frazier's work on Brazil, however, did not go down in the history of the social sciences as powerfully as Herskovits'. Even in recent biographies on this great sociologist, who liked to define himself as a "race man," there is little or no mention of his work on Brazil or the Caribbean. He is generally described as more national than Herskovits. I argue that Frazier was a cosmopolitan, polyglot and internationally oriented scholar, who, in many ways, wanted to do the same kind of grand international comparisons that Herskovits had developed. Frazier failed to leave a durable influence on the Brazilian social sciences, though he certainly spoke to the cultural politics of the Frente Negra (the Black Front.) This group, in the thirties, was the leading strand in black Brazilian thought. It also stressed the universality of the human condition rather than cultural differences, and claimed a valuable place for blacks within modernity (Platt 1990, 1991 and 1996; Teele ed. 2002).

In short, as can be seen from his notes at the Moorland-Spingarn Research Center at Howard University, from the 1940's to the end his life Frazier resented deeply all the obstacles he experienced and that prevented him from becoming the universal scholar he had certainly hoped to be ${ }^{20}$. He was attuned to mainstream sociology throughout his life and the first black president of the American Sociological Association in 1948 (the referees in his application to the Guggenheim Foundation grant for Brazil were no less than Burgess, Park and Wirth.) Nevertheless he stayed unsatisfied with the place of American black intellectuals in mainstream academia and also with the mediocrity and self-complacency of the intellectuals that operated exclusively within the black community ${ }^{21}$. Frazier never went back to Brazil.

Turner, as evinced from his papers at the Melville J. Herskovits Library of African Studies at Northwestern University and from interviews with his son and wife, used recordings, interviews, impressions and even a set of artifacts

20 Frazier Papers, boxes 131-33.

21 See unfinished manuscript “The Negro Intellectual,” Frazier Papers, box 131. 
purchased in Bahia (musical instruments, orixá statues, and candomblé garments) in his teaching and lecturing at universities, secondary schools, and community organizations. Together with his findings on the Gullah language and, later, the Creole language of Sierra Leone, his Bahia findings corroborated his understanding of the centrality of Africa in contemporary black speech. He saw his work as intrinsically transnational and transatlantic, but this was barely recognized by the academic establishment ${ }^{22}$. Turner also never went back to Brazil . ${ }^{23}$

In spite of these important differences, these three scholars also had a number of key similarities. They used their experience and findings in Bahia and Brazil generally as a stepping stone in the founding of African studies in the United States. Turner and Frazier played a key and pioneering role in the establishment of departments of African studies at Fisk (Turner, in 1943) and Howard (Frazier, in the mid 1940's.) Herskovits established the first interdisciplinary African studies program in the United States at Northwestern University in 1948 (Gershenhorn 2004: 169). Even though Herskovits' program would grow and soon develop into the leading one in the United States (it is not by accident that the library specialized in African studies at Northwestern is named after him) one should not underplay the pioneering role of Fisk and Howard in creating African studies and attracting African scholars to the United States. This was, and still is, especially important in internationalizing traditionally black universities.

Furthermore, Turner, Frazier, and Herskovits came to Bahia to test the results of research carried out elsewhere as well as to corroborate their hypotheses on the African origin of black culture. The Gantois house was the common test case and, by and large, they interviewed the same people. And, as it goes, they all found in Gantois the causality what they were looking for, respectively, slavery and adaptation to poverty (Frazier) and Africanisms (Turner for language and Herskovits for family structure.) They also have in common the fact that none of them made Brazil and Bahia the cornerstone

\footnotetext{
22 Olivia Gomes da Cunha was possibly the first Brazilian to point out the importance of Turner's work in Brazil. Pol Briand, a French independent scholar has also recently dedicated his attention to highlight Turner's work in Brazil. See da Cunha Gomes 2005: 7-32.

23 No actual field notes have been found in the two collections of Turner's papers, at Melville Herskovits Library of African Studies, Northwestern University and the Anacostia Community Museum at the Smithsonian Institution. This is obviously a great loss and an obstacle to reconstructing Turner's Brazil experience.
} 
of their studies as they had proposed when applying for funding applications for their Brazilian research. They never wrote a book on Bahia as they had planned.

Bahia was to them a test case of a hypotheses generated within the American political, moral, and racial context. The fact was that black speech and the black family structure were American concerns, not Brazilian. Then and now, scholars and laymen agree that there is no "Black Portuguese," but indeed the use of a language usually defined as Yoruba in candomblé ceremonies and of a plethora of terms of Bantu origin in the Portuguese spoken in Brazil. As for the "black family," the term is still not in use in Brazil, where matrifocality is associated either with poverty or with social mores, not with Africanism (an important exception is Marcelin 1999).

Their research in those days concerned an American battle which was being fought on Brazilian soil, and which never got back to Brazil. In fact information about their work was somewhat repatriated by a white Italian anthropologist (me). That is, very few or none of my colleagues in Bahia knew of the two famous articles by Frazier and Herskovits in the American Sociological Review until I left a photocopy of them at the library of the Federal University of Bahia in 1992. And yet these texts become important in several debates on the black family in the US in the Seventies and again today in the critical re-reading of the classic ethnographies of the time, such as Ruth Landes' (see Fry 2002).

Turner's recordings and photos, in spite of their exceptional value, have remained invisible and unknown to the vast majority of Brazilian scholars until recently. The recent digital repatriation copies of his photos and recordings to the Gantois candomblé house - in sessions organized by the Digital Museum of African and Afro-Brazilian Heritage of the Federal University of Bahia - allowed the older people to recognize most of Turner's informants. They were moved by the opportunity to hear the voices of such important people in the candomble community and gave great value to the recordings of voices of long ago religious leaders. This project is giving a new relevance to Turner's work in Bahia. This process of digital repatriation received the support of the Archives of Traditional Music at the University of Indiana, Bloomington where the collection of Turner's recordings is housed; the Melville J. Herskovits Library of African Studies at Northwestern University and especially of the Anacostia Community Museum of the Smithsonian 
Institution which houses the majority of the photographs and artifacts collected by Turner in his research.

Right from its first steps in the thirties the field of Afro-Brazilian studies, especially regarding anthropology, was a transnational, tense and dense field, intertwined with cultural, racial and political agendas oftentimes originated in the United States and France. This international and even transnational dimension of Afro-Brazilian studies, right from their inception in the academic establishment in the mid-193os to today show that a critical assessment on power and the positioning of knowledge in the United States-Brazil academic exchange is required. This can lead to often painful discoveries regarding the complex and unequal relationship between local contacts (or gatekeepers) in Bahia such as Edson Carneiro and José Valladares and American professors visiting Brazil and Bahia. The former had the local knowledge while the latter, in those days especially when they were white, had grants to offer or connections to American universities. I wonder how the gathering of information and the picture rendered of Brazil by these key informants was affected by the unequal basis of this intellectual exchange. It seems that most of these key Brazilian intellectuals, then and perhaps even now, tend to tell Americans visitors exactly what they are willing to know and "discover." In those days to counteract racial segregation in the United States they were looking for a racial democracy in Brazil and they were given "evidence" of it. In the 1990 s American researchers tended to portray Brazil as a house of horrors (modernity gone wrong) and they were given "evidence" that Brazil was in fact a racial hell ${ }^{24}$. With the advent of the Lula era things changed again and Brazil is now back to being represented as a positive example for the struggle against racial inequalities. A refined perspective on comparative race relations between the US and Brazil, focused on similarities as well as local or national singularities, and a more even and equal relationship between United Statesbased and Brazil-based scholars in this field are still to be developed.

24 In fact, one can argue that the field of ethnic and racial studies has always been a transnational as well as tense scientific field, in spite of the contention of Pierre Bourdieu and Loïc Wacquant that is mostly the result of a more recent internationalization -- or even Americanization - of the academic canons. The debate sparked off by the famous Bourdieu and Wacquant article needs to be historicized and has much deeper historical roots than often assumed, deep down the making of the Brazilian nation. See the special issues of the journals Theory Culture and Society (2003) and Estudos Afro-Asiáticos (available on line on WWW.scielo.br) that were dedicated to debating this polemic article. 


\section{Bibliography}

Amos, Alcione M. Os Que Voltaram: a História dos Afro-Brasileiros que Voltaram para a África no Século XIX. (Belo Horizonte, Brazil: Tradição Planalto Editora, 2007.)

AZEVEDO, Thales de. As Elites de Cor Numa Cidade Brasileira: Um Estudo de Ascensão Social \& Classes Sociais e Grupos de Prestígio. (Salvador: EDUFBA, 1996.), see on line version in French Les élites de couleur dans une ville brésilienne, in vibrant.org.br vol 5, no 1, 2008.

COLE, Sally Introduction, in: Ruth Landes The City of Women, The University of New Mexico Press, 1994 [1947], vii-xxv.

CORRÊA, Mariza. História da Antropologia no Brasil (1930-1960). Testemunhos: Emilio Willems e Donald Pierson. São Paulo: Editora Revista dos Tribunais; Campinas: Editora da Unicamp/Edt. Vértice, 1987.

CORREA, Mariza e Mello, Januária (orgs.). Querida Heloísa/Dear Heloísa: cartas de campo para Heloísa Alberto Torres. Núcleo de Estudos de Gênero, Unicamp, 2009.

DANTAS, Beatriz G. Vovó nagô e papai branco: usos e abusos da África no Brasil. Rio de Janeiro: Graal, 1988

DAVIS, John ed. African from the Point of View of American Scholars (Paris: Présence Africaine, 1958).

DINES, Alberto. Morte no paraiso. A tragedia de Stefan Zweig. Rio de Janeiro: Rocco, 2009

FRAZIER, E. Franklin. “The Negro Family in Bahia, Brazil.” American Sociological Review, 7 (1942), 465-78.

FRAZIER, E. Franklin. “Rejoinder to Melville J. Herskovits” The Negro in Bahia, Brazil: A Problem in Method.” American Sociological Review, 8 (1943),402-04.

FRAZIER, E. Franklin. 1966. The Negro Family in the United States Chicago: The University of Chicago Press.

FRAZIER, E. Franklin. 1942, “Brazil Has No Race Problems.” Common Sense 11:363-65.

FRAZIER, E. Franklin. 1942 b. "Some Aspects of Race Relations in Brazil.” Phylon, (Third Quarter):284-95.

FRAZIER, E. Franklin. 1944. “Comparison of Negro-White Relations in Brazil and in the United States." Transactions of the New York Academy of Sciences, Series 2, 6, 7:251-269. 
FRAZIER, E. Franklin. 1962. "A controversial question: do American Negroes have what Africa needs?" Negro Digest, November, 62-75 (available on line on Google Books). Reprint of the article in John Davis ed. 1958.

FRY, Peter. "Apresentacao", in: Ruth Landes. A cidade das mulheres. Rio de Janeiro: Editora da UFRJ.

FRY, Peter. Presentation of the Special Issue of the on line journal Vibrant on Religion and Sexual Diversity Vol 7. N 1. www.vibrant.org.br 2010 GERSHENHORN, Jerry. Melville J. Herskovits: and the Racial Politics of Knowledge (Lincoln: University of Nebraska Press, 2004), 169.

GOMES, Olivia da Cunha 2005. "Do ponto de vista de quem? Diálogos, olhares e etnografias dos e nos arquivos", Estudos Históricos 36, 7-32.

GUimARAES, Antonio Sergio. "Africanism and racial democracy: the correspondence between Herskovits and Arthur Ramos (1935 1949)". Estudios Interdisciplinarios de America Latina y el Caribe, v. 19, p. 1-22, 2007. GUIMARAES, Antonio Sergio. “A recepção de Fanon no Brasil e a identidade negra”. Novos Estudos. CEBRAP, v. 81, p. 99-114, 2008.

HELLWIG, David J. African-American Reflections on Brazil's Racial Paradise. (Philadelphia: Temple University Press, 1992.)

HERSKovits, Melville. “The Negro in Bahia, Brazil: A problem in Method.” American Sociological Review, 8 (1943), 394-402.

HE RSKOVITS, Melville. The New World Negro: Selected Papers in Afro-American Studies. (Bloomjngton, Indiana: University of Indiana Press, 1966).

LANDES, Ruth. The City of Women. (Albuquerque: University of New Mexico Press, 1964.)

MAC DONALD, J. \& L. Mac Donald. The black family in the Americas: a review of the literature. Race Relations Abstracts 3,1 London:Sage.

MAIO, Marcos Chor . The UNESCO Project: Social Sciences and Race Studies in Brazil in the 1950s. Portuguese Literary \& Cultural Studies, Darmouth, MA - USA, v. 4/5, p. 51-64, 200o. For an overview in English of Maio's work see http://portal.unesco.org/fr/ev.php-URL_ID=30394\&URL_DO=DO_ TOPIC\&URL_SECTION=201.html

MARCELIN, Louis . A Invenção da Familia Afro-Americana: Familia, Parentesco e Domesticidade entre os Negros do Recôncavo da Bahia. PhD Thesis. Graduate Program in Social Anthropology, Museu Nacional, Rio de Janeiro, 1999. PEREIRA, Claudio and Livio Sansone, Projeto Unesco no Brasil: Textos Críticos. (Salvador: Edufba, 2007.) 
PIERSON, Donald 1942. Negroes in Brazil: A Study of race Contact in Bahia. Chicago: University of Chicago Press.

PLATT, Anthony M. 1996. “The Rebellious Teaching Career of E. Franklin Frazier.” Journal of Blacks in Higher Education 13:86-90.

PLATT, Anthony M. 1990. "Racism in Academia: Lessons from the Life of E. Franklin Frazier." Monthly Review 42, no.4: 29-46.

PLATT, Anthony M. 1991. E. Franklin Frazier Reconsidered, New Brunswick N.J.: Rutgers University Press.

PRICE, Richard and Sally Price. The Root of Roots, or How Afro-American Anthropology for its Start. (Chicago: Prickly Paradigm Press, 2003)

SANSONE, Livio, Blackness without Ethnicity: Creating Race in Brazil (New York: Palgrave MacMillan, 2003.)

SANSONE, Livio "Contraponto Baiano do Açúcar e do Petróleo: São Francisco do Conde , Bahia 50 Anos Depois.” In Pereira and Sansone, Projeto Unesco, 194-218.

SPITZER, Leo. Lives in Between: Assimilation and Marginality in Austria, Brazil West Africa, 1780 - 1945. (Cambridge, New York: Cambridge University Press, 1989).

TEELE, James E. 2002. E. Franklin Frazier and Black Bourgeoisie. Columbia and London: University of Missouri Press.

TURNER, Lorenzo Dow. "African Survivals in the New World with Special Emphasis on the Arts." In John Davis ed. African from the Point of View of American Scholars (Paris: Présence Africaine, 1958), 101-16.

TURNER, Lorenzo Dow. 2003. Africanisms in the Gullah Dialect. Columbia, SC: University of South Carolina Press.

TURnER, Lorenzo Dow. “The Negro in Brazil.” The Chicago Jewish Forum, 15 (1957), 232-36.

TURNER, Lorenzo Dow. "Some Contacts of Brazilian Ex-Slaves with Nigeria, West Africa." Journal of Negro History, XXVII (1943), 55-67

VAlladARES, Licia do Prado "A visita do Robert Park ao Brasil, o "homem marginal" e a Bahia como laboratório" Cadernos CRH 23, 58 (2010), 35-49. WADE-LEWIS, Margaret. Lorenzo Dow Turner: Father of Gullah Studies.

(Columbia, SC: University of South Carolina Press, 2007.) WAGLEY, Charles. Race and Class in Rural Brazil. (Paris: Unesco, 1952) WILlIAM, Daryle. Culture Wars in Brazil. The First Vargas Regime 1930-1945.

Durham \& London: Duke University Press, 2001. 
YELVINGTON, Kevin. "Melville J. Herskovits e a Institucionalização dos Estudos Afro-Americanos.” In Pereira and Sansone, Projeto Unesco, 149-72. 2007

YELVINGTON, Kevin. "The invention of Africa in Latin America and the Caribbean: Political Discourse and Anthropological Praxis, 1920-1940", in: Kevin Yelvington ed. Afro-Atlantic Dialogues. Anthropology in the Diaspora. (Oxford: James Carrey, 2006.)

ZWEIG, Stefan and Lotte Zweig, Stefan and Lotte Zweig's South American Letters: New York, Argentina and Brazil, 1940-42. Darién J. Davis and Oliver Marshall, eds. (New York: Continuum, 2010.)

\section{Archival Collections}

DU BOIS, W.E. Papers, 1868-1963, Special Collections and University Archives, W.E. Du Bois Library, University of Massachusetts, Amherst, MA.

FRAZIER, E. Franklin papers, Moorland-Spingarn Research Center, Howard University, Washington, DC

LORENZO DOW TURNER PAPERS, Africana Collection, Melville Herskovits Library, Northwestern University, Evanston (Illinois). 


\section{About the author}

Livio Sansone (Palermo, Italy, 1956) got his Ba in sociology at the University of Rome and MA and PhD from the University of Amsterdam (1992). From 1992 Sansone lives in Brazil where he is associate professor of anthropology at the Federal University of Bahia (UFBA). He is the head of the Bureau of International affair of UFBA and of the Factory of Ideas Program - an advanced international course in ethnic and racial studies - and coordinates the Digital Museum of African and Afro-Brazilian Heritage - www.arquivoafro. ufba.br. He has published extensively on youth culture, ethnicity, inequalities and globalization with research based in the UK, Holland, Suriname, Brazil and, recently, Cape Verde and Senegal. 